\title{
Speaking about Reality: Verbatim techniques in contemporary Finnish documentary theatre
}

\section{LAURA GRÖNDAHL}

\begin{abstract}
During the past years, different modes of documentary theatre have gained popularity. A distinctive feature there is the use of verbatim texts, borrowed directly from authentic documents like recorded interviews or minutes, including sometimes even coincidental stuttering of the original speaker. In this article I analyse the verbatim-technique as part of the post-dramatic performance strategies. It makes it possible to focus on the materiality of language as a texture as well as an instrument for meaning making and communicating contents. It also gives a more active role to the audience. When texts are explicitly framed as authentic, and reiterated with exaggerated precision, the attention is drawn to the performative repetition of the speech acts. Thus, the verbatim performances do not so much refer to reality "as it is", but rather stage acts of making claims about something we call reality. Borrowing Carol Martin, the contemporary generation of documentary theatre makers aspire to make relevant claims about social reality even if they use postmodern strategies and admit that truth and reality are not within their reach. I will discuss different strategies of using the verbatim techniques in documentary performances. I theorize the subject using well-known international examples, move on to a short overview of recent documentary theatre in Finland, and examine closer four cases: Parliament III in Ryhmäteatteri in 2015, Towards Work at Kouvolan Teatteri in 2014, Ruusula Street 10 at Q-teatteri in 2014, and My Palestine at Teatteri Takomo in 2015.
\end{abstract}

\section{KEYWORDS:}

Documentary, verbatim, political theatre, postdramatic, performative, autheticity 


\section{Speaking about Reality Verbatim techniques in contemporary Finnish documentary theatre.}

Although they are no new phenomenon, different forms of documentary theatre have become unprecedentedly popular in the early 2000s. Instead of a fixed genre, there seems to be a variety of different practices of using recorded speech, authentic documents and witnesses as the primary, if not exclusive, material for the scripts. Documentary theatre is also called verbatim, which literally means "in the exact words, word for word"1, because the spoken or written documents are often repeated in their original form in detail. To quote Derek Paget, the authentic source material "becomes the true protagonist in the drama." 2 The verbal language has thus a special role operating in-between the performative event and the socio-historical reality beyond theatre.

In this article, I will examine how verbatim-techniques are used within recent Finnish documentary theatre performances. How do theatre makers collect quotations from various sources and frame them as authentic fragments from everyday life? How do they perform statements that are supposed to be taken as true? The key question is the relation between the raw data of the verbatim fragments and the knowledge that is produced by performing these spoken words on stage. Before presenting the Finnish cases, I will discuss some theoretical aspects of verbatim techniques in documentary performances using well-known international examples as a starting point.

\section{THE REPETITION OF SPEECH ACTS}

Anna Deavere Smith is, undoubtedly, one of the most prominent verbatim artists having dealt, for instance, with ethnic riots and debates on American health care. In her one-woman shows, she created a kind of living sound- 
portrait of real people, representing different viewpoints or experiences from the same events. She not only reduplicated the recorded interviews word for word, but also mimicked the emblematic intonation and prosody of the speakers. Although I, unfortunately, have only seen Fires in the Mirror (1992) and excerpts from Let Me Down Easy (2008) on video, I had a phantasmal illusion of two bodies connected by the same speech. ${ }^{3}$ As the theatre scholar Diana Taylor describes it: "[Smith] allows her body to channel (rather than own) a whole range of positions. [--] Smith has stated that an actor can get inside a character through language; if we learn to say the words of another, we will be able to somehow feel what the other feels and understand why others do as they do."4

Taylor has introduced two theoretical concepts, which might be helpful in understanding the functioning of verbatim techniques. Archive and repertoire are different epistemic modes of storing and transmitting knowledge. Archived knowledge is preserved in enduring materials like verbal texts or artefacts, while repertoires exist as embodied practices and, therefore, require the presence of bodily human agents. ${ }^{5}$ The oral speech, which consists of both aspects, can be seen as a liminal and mediating practice between the fixed information of recorded facts and the ephemeral, tacit knowledge contained in the prosody and gesticulation of individual speakers.

To me, it felt as if Smith had taken another person's oral repertoire from the original body and put it into her own mouth. The verbatim technique broke the uninterrupted continuity between the speech contents and the speaking body, typical for everyday communication. The way of speaking appeared as a clue of the speaker's mind-set, carrying marks of his/her social, ethnic, or gendered position and personal background. Smith describes her method as an application of Brechtian gestus, a physical gesture that indicates an attitude, especially concerning social class and power positions. The gestus does not denote psychological processes but socio-historical structures that are manifest in the behaviour of individuals, who represent certain social groups. To make this visible, the actor should present the gestus as something separate from his/her own being. Similarly, Smith's verbatim-technique seems to alienate the oral repertoire from its natural context in order to make the very speech act into an object for critical investigation.

3. Fires in the Mirror, https://www.youtube.com/watch?v=hnkrUJny0CE; Let Me Down Easy: https://www.youtube.com/watch?v=uQ1OyKy9FwM.

4. Taylor 2003, 230.

5. Taylor 2003, 19-20. 
Alecky Blythe has developed the verbatim technique even further by letting her actors wear headphones from which they hear their lines at the same moment they recite them. According to her, this leads to an unusual intensity since the actors are forced to listen to the text while they speak. They do not get too familiar with the contents and have no time to interpret or embellish it. ${ }^{6}$ The actors, thus, repeat the speech in every detail without separating irrelevant stuttering from meaningful words because, according to Blythe, "there is always a specific reason why a person stutters on a certain word, and it is this detail that gives the characters such startling verisimilitude." 7

At first sight, this resembles realistic strategies, where the protagonists reveal their private mind through public behaviour and the outer appearances can be interpreted as readable signs of hidden psychological structures. Yet, the authentic speech in Blythe's verbatim technique is presented in its raw materiality and the role of the actor seems instrumental. Instead of trying to figure out the private processes behind a certain public behaviour, s/he becomes a kind of living playback device, who blindly mediates signs without adding his/her own interpretation to the acting.

Yet, the spectator-listener is left in uncertainty about the significance of the "ers" and "ums". The very act of repeating them suggests that they carry some meaning. However, one cannot know why the speaker stutters during the speech: is s/he trying to hide a lie, or did s/he just get something stuck in the throat? This resembles the principle of immanence, which according to Richard Sennett constituted the materialistic epistemology of early realism: "everything counts because everything might count." If there is no transcendental way of knowing the world beyond the experience of its materiality, everything must be taken as a potential symptom of some deeper lying cause. This effect might partly explain why verbatim performances are often received with the uttermost intensity even when there is no dramatic action or plot to follow. Robin Soans describes his experience as a verbatim actor: "Not only were these people following my every syllable, but they were emotionally bound up with me as well. In all my years of acting, I had hardly ever had such keen attention paid to me."9

Soans argues that verbatim theatre, which mostly consists of soliloquies rather than dialogues and stage action, activates its audience differently from
6. Hammond \&Steward 2008, 80-81.
7. Hammond \&Steward 2008, 97.
8. Sennett 1978, 21.
9. Hammond \&Steward 2008, 22. 
traditional drama. It places the spectator in the role of a conversational partner to whom the characters confide and who thus feels personally involved in their dilemmas. ${ }^{10}$ The uncertainty about the hidden meanings may heighten emotional intensity as the spectators try to understand the words by linking them to their own experiences. The listening becomes an active process, which moves the focus from the stage action to the audience reception.

\section{THE EPISTEMIC ROLE OF THE SPECTATOR}

It is the spectator who ultimately constructs the story around the immanent verbatim evidence played in front of him/her. Yet, s/he can never know the other behind the words. The impossibility of a definite interpretation leads to an epistemic uncertainty, which draws attention to the surface of the speech: the very same literal word-to-word phrase may carry different meanings depending on the ways of saying and receiving it in a particular context. The documents do not only tell of the past, as it was; they also participate in the production of new interpretations about the past. As Will Hammond puts it, "verbatim is a re-contextualising process." 11 In this process, the literal quotation is separated from the original act of saying it and used as a component in new speech acts and events that produce new meanings in the performance. When the spectators live through these acts of re-contextualisation, they also add their personal memories, emotions and attitudes to the process of meaning making and interpretation.

The move of focus from the authors' intentions to the spectators' reception is emblematic for all contemporary theatre and art. Erika Fischer-Lichte calls it the "feedback loop" between performers and audiences. The contents of the artwork emerge from an unpredictable, interactive process, and cannot be determined before the event. ${ }^{12}$ In phenomenological terms, the artwork is always something new that is in a state of becoming. Applied to documentary theatre it means that the interactive feedback loop can produce new understandings that cannot be determined beforehand. This is linked to the postdramatic move, where theatre performances turn away from representational strategies to presentational ones: the verbatim technique exhibits the recorded speech in its raw presence, which has a potential to become meaningful statements about reality. How this potential gets actualized depends, however, on the reception. The spectator now becomes responsible for the

10. Hammond \&Steward 2008, 23.

11. Hammond \&Steward 2008, 73.

12. Fischer-Lichte $2008,39$. 
conclusions drawn from the performance. As Richard Norton-Taylor, the author of tribunal plays at the Tricycle Theatre in London, puts it: "we represented the facts, leaving, as the playwrights of ancient Greece did, the audience, in the role of the jury, to make up its own mind."13

The German theatre director Boris Nikitin calls documentary theatre a radical form of illusion based on different kinds of "credibility techniques" (begläubigungstechniken), whose purpose is to make the audience believe in the authenticity of the performance. Such techniques may involve tangible evidence, recordings, authentic photos, or the introduction of the actors' civil identities. However, their effect is ultimately an illusion and the possibility of falsity always exists. ${ }^{14}$ In Nikitin's view, this uncertainty about the authenticity of a document democratizes knowledge because it is finally up to the spectator as to what truth $s /$ he is willing to accept. The spectator does not only interpret the performance; s/he also evaluates its truthfulness in relation to the reality beyond the theatrical sphere.

\section{THE PERFORMATIVITY OF THE TRUTH}

In terms of language, the relation between a verbal utterance and its actual effects on receivers was thoroughly examined by J.L. Austin in his classic speech act theory presented in $1955.15 \mathrm{He}$ made a difference between a constative utterance, which is a factual statement and can thus be evaluated as true or false; and a performative one, which is able "to do things by words". A performative statement can achieve no truth-value, but it can succeed or fail depending on the validity of the context and participants of the speech act - or as Austin formulated it, a speech act can be happy or unhappy. For example, when an authorized person recites the wedding formula on a specific occasion, s/he can turn two single people into a married couple. Austin drew the conclusion that the efficacy of a performative act was not in the locution (the literal meaning of the words and syntax) but in the appropriateness of the procedures and situation: the identity, behaviour, attitude and intention of the participants. ${ }^{16}$ Although Austin excluded theatre and other "parasitic" modes of language from his discussions, because they are not valid in ordinary circumstances, his theory has proved useful in understanding how public repetition of certain utterances or actions can constitute the cultu-

13. Hammond \&Steward 2008, 113.

14. Nikitin 2014, 13-14.

15. Austin 1962.

16. Austin 1962, 98-107. 
rally conceived essence of things in society. ${ }^{17}$ In the theatricalized society, based on endless quotations, it has become ever harder to tell the difference between "parasitic" and ordinary utterances. Even the documentary theatre is an example of this mixing of fact-based and fictive discourses: serious truthclaims are presented by an actor whose speech acts would normally be received as pretence.

Although most verbatim quotations should be categorized as constatives that describe something, in the context of a documentary play they are also presented as truthful evidence from past events and utterances. Their credibility depends on a successful performance that can convince the audience about their authenticity. A verbatim sentence in a documentary play thus works like a performative act, which attempts to verify its own information at the moment of saying it. It also differs from fictive drama because the claim for truthfulness extends to the reality beyond theatre. Moreover, similarly to a performative speech act, the audience must confirm the claim by accepting the appropriateness of the speaker and the situation. In Austin's terms, a verbatim speech act is both a constative, which gives information, and a kind of performative act that tries to guarantee its own truthfulness. The spectators decide whether the statement can be happy (as Austin would say), or in other words, the documentary value of a verbatim speech acts depends on the success of its performative efficacy.

The French philosopher, Jean-Francois Lyotard suggests, in his classic book on postmodern conditions in 1979, that contemporary culture is based on a performative epistemology. ${ }^{18}$ The legitimation of knowledge takes place through different language-games since it cannot be anymore grounded on the modernist meta-narratives or fixed relations between signs and objects. The truthfulness of a statement depends on its efficacy in terms of the particular games in which it participates, not on its correspondence with the empirical world or transcendental ideas because these are not accessible to the human mind. The truthfulness of a statement is based on its performance in a certain discursive context, or simply put: your statement becomes true if you can make the receivers believe it by performing it successfully within the given rules.

Postmodern thinkers have basically rejected the notion of documentary as a direct relation to reality. For example, theoretical discussions on documentary film have, since the 1990s, largely resulted in the conclusion that fiction and 
nonfiction cannot be distinguished and that the truth always manifests itself in narrative structures. ${ }^{19}$ If everything is understood through language games and simulations, if everything exists as a copy of a copy, there is no place outside the representational system from which the world could be objectively observed. ${ }^{20}$ For the same reason, postmodern art can only be political by deconstructing its own discursive means of representation, which again are conditioned by ubiquitous capitalism, outside of which you can never get.21 According to Hans-Thies Lehmann, the post-dramatic theatre has lost its traditional political functions as a medium that can have influence on society. ${ }^{22}$ The only way it can be political is to reflect on the performative means it uses and question the established hierarchic order of perception and knowledge. ${ }^{23}$

Yet, many contemporary documentary theatre makers seriously claim that they are speaking of reality and searching for truth, while investigative journalists have turned to the medium of theatre because they feel that the traditional news media have lost their function and reliability in explaining the complicacy of the present world. ${ }^{24}$ Carol Martin calls their attitude "constructivist postmodernism". Even if these documentarians use postmodernist strategies admitting the relativity of the "truth" or "real", they believe that meaning can be within their reach: "A new generation of artists and scholars is committed to understanding theatre as an act of positive consequence."25

In the following, I will discuss Finnish documentary performances, asking how the authors negotiate between the political urge of making relevant claims about society, and the postmodern awareness that we never have access to any truths beyond the raw data of material documents. My key question is, how the documentary theatre makers construct the role of the spectator as the ultimate interpreter and judge of the knowledge that is produced through the performance.

19. Renov 1993.

20. Rosen 1993, 82-84.

21. Auslander 1992.

22. Lehmann $2009,406$.

23. Lehmann $2009,412$.

24. e.g. Hammond \&Steward 2008, 31; 108, Junttila 2012, 25; 156-159, Reinelt 2009, 12, Kuparinen 2013, 17; Haapala, interview 27.2.2014.

25. Martin 2010, 3-4. 


\section{DOCUMENTARY THEATRE IN FINLAND IN THE 21ST CENTURY}

The contemporary wave of documentary theatre surfaced in Finland in 2008-10 when the journalist and director Susanna Kuparinen, together with her team, staged three performances based on the minutes of the Helsinki city council. ${ }^{26}$ Another trilogy about the Finnish Parliamentary sessions followed in 2011-15.27 Kuparinen writes in her MA-thesis from 2013 how she developed her method as a reaction to the increasing economic inequality in society, and the lack of critical political discussions in the mainstream media. ${ }^{28} \mathrm{Her}$ starting point was Denis Guénoun's idea of theatre as a political gathering. ${ }^{29}$ Combining journalistic and theatrical practices, she aspired to create documentary performances that work like a popular assembly where different opinions can be presented and discussed. ${ }^{30}$

When mapping the popularity of documentary plays in Finland after Kuparinen's breakthrough in 2008 , I found roughly 40 performances that were defined as more or less documentary by their makers or reviewers. ${ }^{31}$ Their themes varied from national history and daily politics to topics such as: unemployment, refugees' experiences, trafficking, immigration, marginalization, mental problems and autobiographical stories. Although documentary theatre seems marginal in comparison to the total number of plays staged in Finland annually, 32 and although the genre was acknowledged remarkably la-

26. Valtuusto - eli kuinka pienistä asioista tulee suuria ja suurista pieniä. (The City Council - or how small matters become big and big ones become small) 24.2.2008.

27. Valtuusto II - välikysymys (City Council II - the interpellation) 20.10.2008, Valtuusto III - uusi etulinja (City Council III - new front line 5.9.2010. Eduskunta (Parliament) 4.3.2011, Eduskunta II (Parliament II) 27.9.2012, Eduskunta III (Parliament III) 26.9.2015.

28. Kuparinen $2013,17$.

29. Kuparinen 2013, 24.

Guénoun, 2007. According to Guénoun, the theatre spectators become aware of the political potential as a community because they can perceive each other's presence. In Guénoun's thinking, theatre is politically constituted, but it should not be used as a forum for actual political activity. The mission of theatre is to pose metaphysical questions and turn the unperceivable into the perceivable (48). Kuparinen has obviously taken only part of Guénoun's idea, ignoring the metaphysical aspect.

30. Kuparinen $2013,33$.

31. The main sources of the survey 2018-14: Ilona-database, Theatre Info Finland: theatre statistics, newspaper archives, homepages and Facebook walls of singular theatres and performances. Between September 2014 and December 2015, I went to see every performance I suspected as documentary.

32. There were 471 different performances in Finnish drama theatres subsidised by the state in 2014. (Tinfo Theatre Statistics 2014.) 
ter in Finland than for example in Germany or the UK, it has now aroused keen interest and become part of public discussions as the following cases show.

Moreover, beyond and before Kuparinen's emergence, authentic materials and verbatim texts had been frequently used in contemporary theatre. Instead of a fixed genre, there seemed to be an ample grey zone between fact and fiction. Only a few theatre makers define their performances as explicitly documentary, although they deal with current and factual social issues. For example, Vaara-kollektiivi, a group-theatre based in Kajaani, created a performance on the ecological disaster and bankruptcy of the nickel mine Talvivaara and marketed it as a "combination of journalism, hi-tech stage technologies and fiction". ${ }^{33}$ This may be a simple backup strategy for permitting more artistic freedom. Then again, by calling the performance "a local science fiction", the team implied that the factual disaster of Talvivaara was a result of reckless and unrealistic visions, and that the real events were more unbelievable than any invented stories. The blurring of facts and fiction could be read both as an artistic and political comment.

Contemporary theatre makers have frequently created experimental performances by compiling verbatim texts or other unaltered pieces of reality found in the world. For example, the dramatist and director Katariina Numminen described her activity as "reversed, pervert playwriting" since she tries to fade herself completely out of the picture as an author in the plays she directs. ${ }^{34}$ She does not want to invent one single word in her play writing, instead she recycles already existing text fragments, such as randomly recorded conversations of anonymous visitors to the Helsinki zoo. ${ }^{35}$ She did not necessarily write down the lines of her plays at any phase because she fancied the ephemerality, randomness and changeability of the oral speech. ${ }^{36}$ Although Numminen clearly benefitted from documentary techniques as part of her works, she did not define her performances as documentary theatre. The verbatim speech was rather used as a music-like texture in the performance event, mixing with other materials and creating a new reality through its immanent presence. $^{37}$

Numminen, like many other contemporary theatre makers, was influenced

33. Talvivaara - kainuulainen scifinäytelmä, (Talvivaara - a Science Fiction Play from Kainuu) Vaara-kollektiivi 3.4.2014.

34. Numminen 2010, 36.

35. Zoo, Zodiak Centre for New Dance 9.3.2014.

36. Numminen 2010, 34-5.

37. Numminen 2010, 31. 
by Lehmann's theory of post-dramatic theatre, which was translated into Finnish in 2009. ${ }^{38}$ According to Lehmann, the only existing reality is the immanent presence of the performance event, which creates meanings, but cannot be interpreted as representations of the socio-political reality. ${ }^{39}$ The document is seen as material to be used in unpredictable artistic processes rather than as evidence of a past event. This mind-set resonates also with the paradigm of artistic research, which was established and even made hegemonic in Finland during the 2000s. In this context, an artwork can be understood as an alternative way of knowing the world on its own poetic terms. A theatrical event can serve as a research method that allows the artists and audiences to examine the world by means of the performance. This means that theatre does not only represent, but also actively produces relevant knowledge.

An opposite example of the use of documentary materials can be taken from the field of popular entertainment. The sketch-show All my Mothers, All my Daughters (Kaikki äitini, kaikki tyttäreni) in Suomen Komediateatteri was based on letters sent to the magazine Kodin Kuvalehti by its female readers struggling with the complexity of their mother-daughter-relationships. ${ }^{40}$ Although the letters were carried on stage in a big basket at the beginning of the show, the word "documentary" was never used in the marketing or reviews, perhaps because of its serious and political connotations. Generally speaking, documentary techniques are common in the entertainment industry; for instance, in different forms of reality-television and games with "ordinary" people as players. According to Carol Martin, there is a "larger cultural obsession with capturing the 'real' for consumption" and the documentary theatre can also be seen in relation to such tendencies. ${ }^{41}$

\section{PARLIAMENT III - PERFORMING RIVALLING TRUTHS}

Parliament III, the closing piece of Susanna Kuparinen's second trilogy premiered on 26.9.2015 at Ryhmäteatteri in Helsinki, performed to fully booked auditoriums and was broadcasted nationally during the next summer. ${ }^{42}$ The key point of Parliament III was to criticize the strict austerity policy of the newly elected right-wing government of Finland. The team carried out thorough background research on the day-to-day governmental decision making processes. The performance's textual material consisted mostly of verbatim

38. Lehmann, 2009.

39. Lehmann, 2009, 178.

40. Kaikki äitini, kaikki tyttäreni (All my Mothers, all my Daughters) 26.9.2013.

41. Martin, 2010, 1.

42. Eduskunta III (Parliament III), YLE Teema 6.8.2016. 


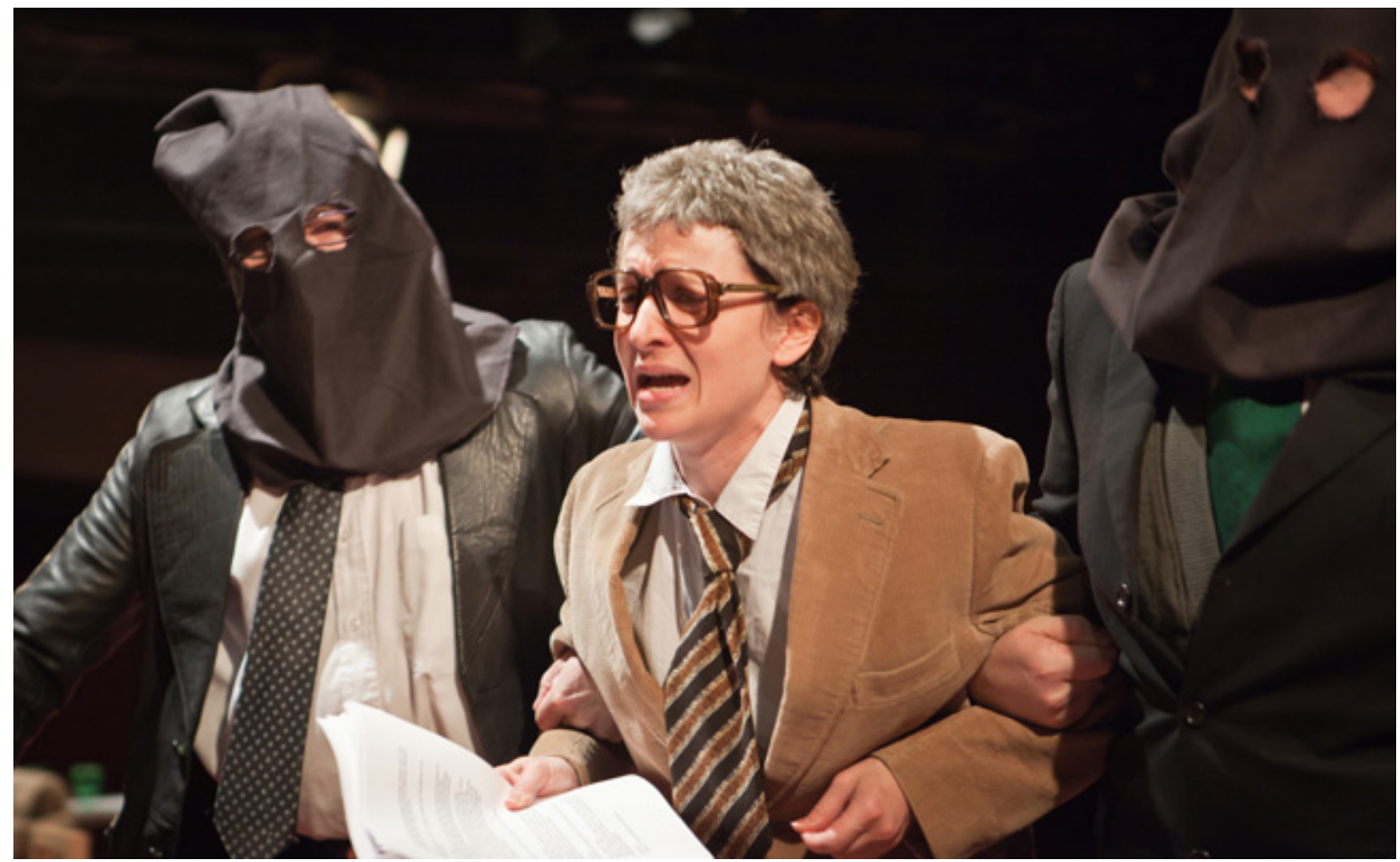

FIGURE 1. Ryhmäteatteri: Parliament III (Eduskunta III) by Susanna Kuparinen and the team, premiere 26.9.2015. In the photo Noora Dadu.

Photographer Ilkka Saastamoinen.

citations from official minutes, proceedings and interviews, supplemented by the team's conclusions. Basically, there were three kinds of scenic materials: the journalist Jari Hanska gave informative lectures on Finland's political economy; Kuparinen interviewed the previous financial minister of Greece, Gianis Varoufakis on video, and the actors performed carnivalesque sketches commenting on recent political events.

Parliament III could not have been premiered at a more propitious moment. The government stumbled from crisis to crisis and lost much of its popularity and credibility. 30000 people participated in a demonstration in Helsinki 18.9.2015, only one week before the premiere. The authors of Parliament III did not try to hide their leftist stance. Kuparinen justified the bias - similar to many other Finnish documentary theatre makers - by noting that the opposite viewpoint already had better visibility in the mainstream media while the performances offered alternative information. ${ }^{43}$ This indicates that the performance was consciously made to work as part of a wider political discourse; it was also received in that context. Most reviewers concentrated their comments on political arguments and journalistic principles, largely overlooking aesthetic choices. Conventionally thinking, the mise-en-scéne was clearly un- 
finished. ${ }^{44}$ The actors read their lines from the scripts and the scenes were simple. Yet, most spectators seemed to be listening intently and I was never bored during the three and a half hour-long performance. Parliament III probably responded to the current emotions and concerns of its audiences with such an efficacy that the artistic criteria faded into the background. As I saw it, the play operated like a political talk-show on TV rather than as an aesthetic experience.

It was possible to identify several "credibility techniques" in the performance, to borrow Nikitin's terminology. The artistic incompleteness reminded one of the hectic tempo of a newsroom, indicating that the team had updated the information up to the last minute, and were focusing only on the essentials. The politicians were presented as carnivalistic, unambiguously exaggerated caricatures, which could perhaps be compared to the allegorical figures of a morality play. An actor also impersonated Kuparinen, who considered her caricaturized role-figure as an important yardstick indicating that everybody was exaggerated in the same way. ${ }^{45}$ However, there were two serious characters, who seemed to be performing as "civil persons" transmitting reliable information stripped from the theatricality of the other figures: Hanska, as a kind of a news anchor, and Varoufakis, as an expert in financial politics. Focusing only on the information they wanted to share, they appeared as two voices of reason, representing investigative journalism and economic sciences. Since Varoufakis was shown only on video, he appeared almost like a transcendental figure talking from another, distant position. The videoclips started with an image of the Acropolis in Athens, which created a mental association with a Greek oracle representing the ancient ideals of democracy.

Kuparinen calls her performance strategy polyphonic, basing it on Mikhail Bakhtin's notion that truth emerges from the dialogical interaction of people who are looking for it: "The notion of objectivity is an illusion. The reality is a sample of rivalling stories that are mostly heard because of the person who is speaking not because of the contents being true or based on facts. ${ }^{46}[--]$ The mission of journalism is to display the rivalling stories; admit and reveal their narrativity of the reality, and to show how the chosen story is angled and interpreted. However, it should frame and select the story with the ethics of a documentary writer, so that the scale is as truthful as possible and the facts

44. Hallikainen 2015, Kangas 2015, Mahlamäki 2015, Porokuru 2015, Suni 2015, Talvitie 2015, Vuorenrinne 2015.

45. "Tervetulosanat" ("Welcome Words") YLE Teema 6.8.2016.

46. Kuparinen $2013,60$. 
hold true."47

Kuparinen was obviously concerned about the performative epistemology, where statements can become "true" if they are only uttered by a "proper" person, in an appropriate situation, regardless of the fact-based evidence. As a journalist, she aspired to investigate the facts behind the rivalling stories and expose the mechanisms of how hegemonic truths are constructed. Yet, since she has chosen theatre as her medium, she also ended up defending her viewpoints by performative means, by staging some speakers and their statements as more convincing than others. To what extent did Parliament III thus duplicate and enforce exactly the same epistemological model it was supposed to criticize?

As a political manifesto, it was certainly trapped in the unavoidable conditions of political language games. The rhetoric was sometimes so tendentious that it provoked spontaneous counter-reactions in my personal reception, even if I could agree with many of the claims. Yet, it was impossible to forget that we were ultimately watching theatre, where you can never be sure about the seriousness of anything. Whether intended or not, this awareness of the overall theatricality generated a persistent doubt towards everything that was said. I started instinctively to ask, what other arguments there might be, attempting to recall what I had read elsewhere. Perhaps one could say that the opposing opinions were present through their absence. From this viewpoint, the performance operated on two levels, both as openly political speech acts and as critical reflections of its own rhetoric. The critical level was an effect of the spectator's reactions as part of wider public discussions and it could not be controlled, nor anticipated by the theatre makers.

\section{TOWARDS WORK - THE THEATRICAL AMENDMENT}

Another documentary theatre production called Towards Work (Työtä päin) premiered in November 2014 at Kouvola Theatre, a medium-sized institutional theatre in South-eastern Finland. 48 The performance was directed by Satu Linnapuomi, who knew Kuparinen's journalistic approach well. ${ }^{49}$ The performance dealt with the change of working life in Kouvola, a middle-sized town typically built around a paper mill. The closing of the factory has devastated the old life style, positioning the local citizens and policy-makers face-to-face with new conditions. The play-text, written by the journalist Laura Haapala

47. Kuparinen 2013, 76.

48. Työtä päin (Towards Work) 8.11.2014.

49. Linnapuomi, interview 23.1.2015. 
was based exclusively on verbatim material. Part of the text was composed into songs, which gave the performance a joyful and entertaining character. The performance was well received by reviewers and audience alike, however it did not sell very well, perhaps because of the strangeness of the documentary genre in the provincial context.

The play consisted, roughly speaking, of three kinds of texts that gave different perspectives on the subject matter. Anonymous inhabitants of Kouvola told their experiences of unemployment and short-time jobs; local policy-makers suggested visions and strategies for the future, and nationally known experts and politicians gave analyses on the overall national and global situation. Two actors depicted Haapala and Linnapuomi as author-characters who gathered information and discussed the script throughout the performance.

Linnapuomi and Haapala took special interest in the verbatim-technique because of the unpredictability of everyday speech: unlike well-written dramatic dialogue, it is fragmentary and inconsistent; the train of thought jumps randomly from one issue to another; and no dramatic arc unites the lines. ${ }^{50}$ According to Linnapuomi, it somehow cancels the spectator's disbelief based on conventional expectations of how "real" people would behave. Because of their personal speaking styles, the residents of Kouvola appeared as identifiable individuals from everyday life. I felt as if I had met them informally at a coffee table, which confirmed their reliability as first-hand witnesses of the grass-root conditions of modern working life.

The second half of the play was more conceptual. Different specialists, politicians, scholars and even institutions were embodied on stage as symbolic representations of certain life styles or attitudes rather than individual persons. Their opinions were juxtaposed and commented on through stylized mimes. The language was now more literal and many quotations were taken out of written sources. The local policy-makers were situated between the identifiable everydayness of spoken language and the more conceptualizing talk of theoretical discourses. They were staged as gently ridiculed figures who tried to solve local problems by adjusting to global development, but were obviously doomed to fail. For example, the social democratic president of the city council had a piece of pink chunky knitting in his hand, which I took as a sign of his helplessness in the face of social changes.

Another scene showed three men in a sauna. Two of them were unemployed paper mill workers, who had wrapped towels around their waists and

50. Linnapuomi interview 23.1.2015, Haapala interview 27.2.2015. 


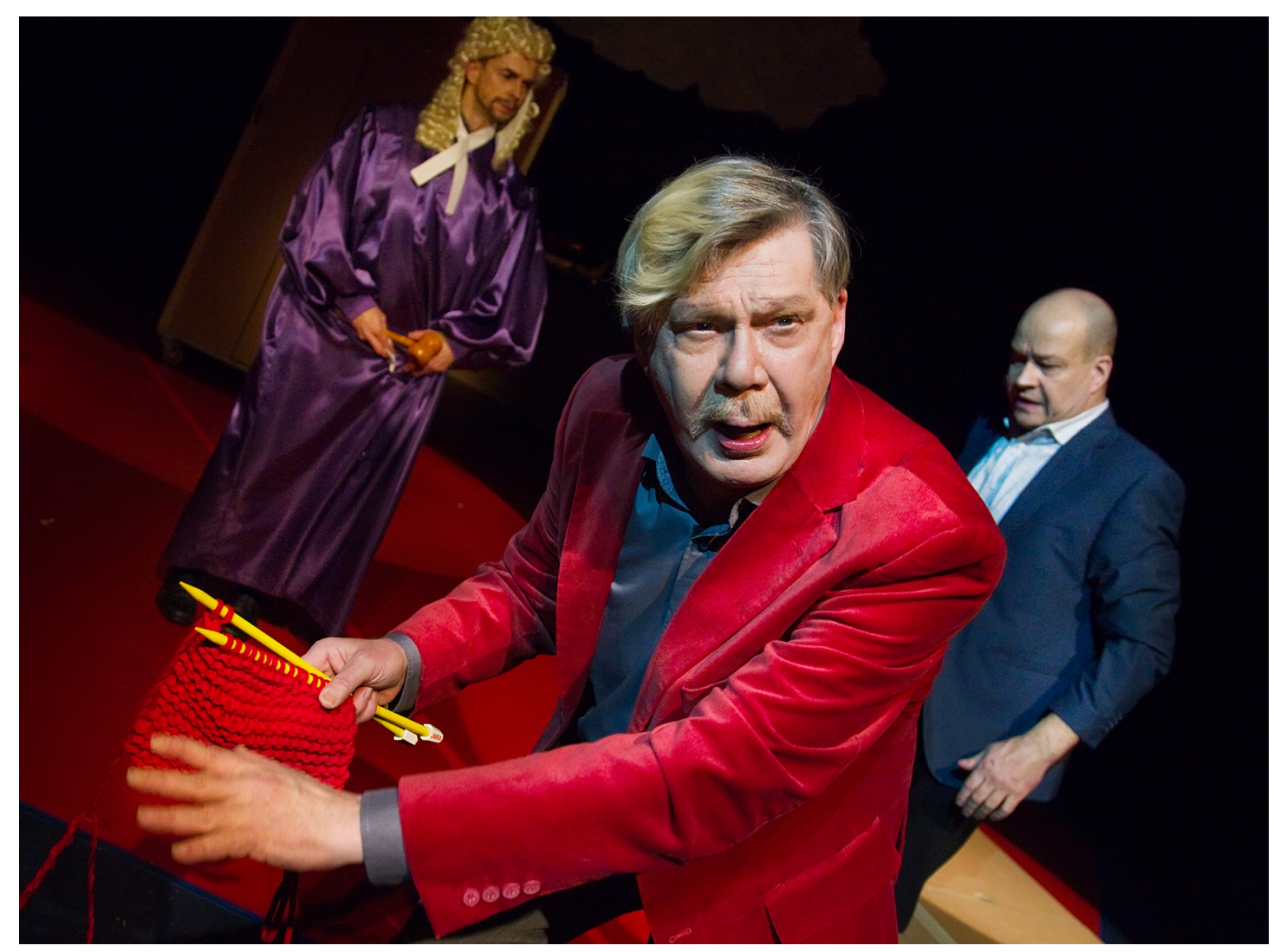

FIGURE 2. Kouvolan Teatteri: Towards Work! (Työtä päin!) by Laura Haapala and Satu Linnapuomi 6.11.2014. In the photo IImo Ranne, Sami Kosola and Raimo Räty. The photographer Marja Seppälä.

between them sat the development manager of Kouvola wearing only a huge tie and underpants. Their dialogue consisted of verbatim quotations from their interviews, which were done separately as one could see in the references projected on stage. The scene was thus composed as a montage, where different authentic documents and fictive images were juxtaposed creating new associations. The well-meaning explanations of the development manager appeared as empty words in relation to the barren stories of the unemployed men. On a symbolic level, the sauna could be seen as a place where everybody enters naked and stripped of pretentious appearances and jargons. The different outfits of the characters implied that the manager was still trapped in his role, which alienated him from the practicalities of real life.

According to Linnapuomi, the caricaturizing was meant to protect the private persons behind the characters: the spectator should understand that the stage-figures were not realistic imitations but the theatre makers' statements added to the recorded texts. ${ }^{51}$ In order to follow the journalistic guidelines of 
transparency and openness, Linnapuomi wanted to make a strict distinction between the verbatim quotations and the bodily theatrical acts. The following text was projected on the curtain at the start of the performances: "All lines in the play are authentic; they are thus true. The stage events and interpretations of individuals are imagined; they are thus theatre."52 By emphasizing the distinction in a very Brechtian way, the authors drew attention to the archive and repertoire as separate aspects of knowledge. However, their intention was not to reveal the mind-set of the represented speaker, but rather the effects of theatricality as a performative amendment to the verbatim text. The spectator received the information in two opposite ways simultaneously, both as fact and fiction, and was thus reminded of their co-existence and inseparability. There was an enlightened strategy of inviting the spectator to reflect critically on the knowledge transmitted by the performance, trusting his/her capability to think and make conclusions. On the meta-level, it could also be seen as another "credibility technique": you are more likely to believe something when you have actively participated in the reasoning.

\section{RUUSULA STREET 10 - LENDING ONE'S VOICE TO "THE OTHER"}

The performance Ruusula Street 10 (Ruusulankatu 10) ${ }^{53}$, at Q-teatteri, told the life stories of young homeless men who lived in a newly founded shelter in the area of Töölö in Helsinki city centre. The placement of the homeless shelter in 2012 had aroused a heated "nimby"54-reaction in the affluent, middleclass neighbourhood. Exaggerated news about several disturbances caused by its residents spread in the media. The local neighbourhood association, the Töölö-movement, took an initiative to settle the situation and correct the false information. 55 Jonna Wikström, the outreach artist56 of Q-teatteri, responded to their call for actions that would promote reciprocal understanding. Being trained within the fields of pedagogy and applied theatre, she arranged workshops for the residents of the homeless shelter. She got to know them and their life-stories through giving them simple theatrical exercises. After one-and-half years of intensive sessions, she compiled a script out of the material she had recorded at the meetings. The resulting performance, Ruusula Street 10, premiered in September 2014. It consisted of soliloquies and dialo-

52. Translation LG.

53. Ruusulankatu 10 (Ruusula Street 10) 17.9.2014.

54. nimby = "not-in-my-backyard"

55. Sivonen interview 9.3.2015.

56. Audience outreach work is a relatively recent area, which aims at activating audiences and engaging new spectators by different participatory means. 
gues performed by two professional actors, and video-clips from the workshop-sessions proving the authenticity of the material. At the beginning of the show, an anonymous voice read excerpts from hate mails addressed to the homeless shelter. There was also a lengthy video from an informative public meeting with Töölö inhabitants, city councillors, representatives of the shelterworkers and police. The performance was a success and the participants of Wikström's workshops gave good feedback. ${ }^{57}$ There was, however, no evidence of the hoped effect on the opinion of the people living in Töölö, since the "nimby" reaction had already calmed down by itself before the premiere. ${ }^{58}$

The shelter residents were young men in their early twenties; many of them were drug-users and had criminal records. Wikström was primarily interested in their personal stories instead of generalizing sociological explanations. She wanted to reject stereotypical characterizations and show that the residents had different backgrounds and reasons for their fates. ${ }^{59}$ She described the rehearsals: "We did not try to imitate anybody, but worked through the contents. We were all the time aware that this is our interpretation. We had the material, what the others had spoken and we figured out what it told us and how it could manifest [in acting]. We tried to understand the motives of the speaker and why he says what he says."60

Consequently, the actors rehearsed their lines like a normal play without meeting the residents. In the performance, they addressed their speech directly to the audience telling the stories in a realistic tone. I had the feeling of listening to the authentic meetings, where the residents looked back at their pasts and shared their present feelings with me. The gap between the document and its representation faded away and the actors seemed to speak sincerely from their own experiences. Yet, the situation was clearly theatrical in the sense that the stories were framed as subjective memories performed before a live audience.

This reminded me of Freddie Rokem's book, Performing History, where he suggests that an actor can perform as a substituting witness speaking up on behalf of absent victims, who are not able to tell their own stories about traumatic historical events. ${ }^{61}$ Rokem calls the actor a "hyper-historian", who can take the place of the dead witness and serve as a link between past and present. Although Rokem excludes documentary theatre from his discussions

57. Wikström, interview 23.10.2014.

58. Sivonen, interview 2015.

59. Wikström interview 17.9.2014 and 23.10.2014.

60. Wikström interview 23.10.2014.

61. Rokem 2000. 


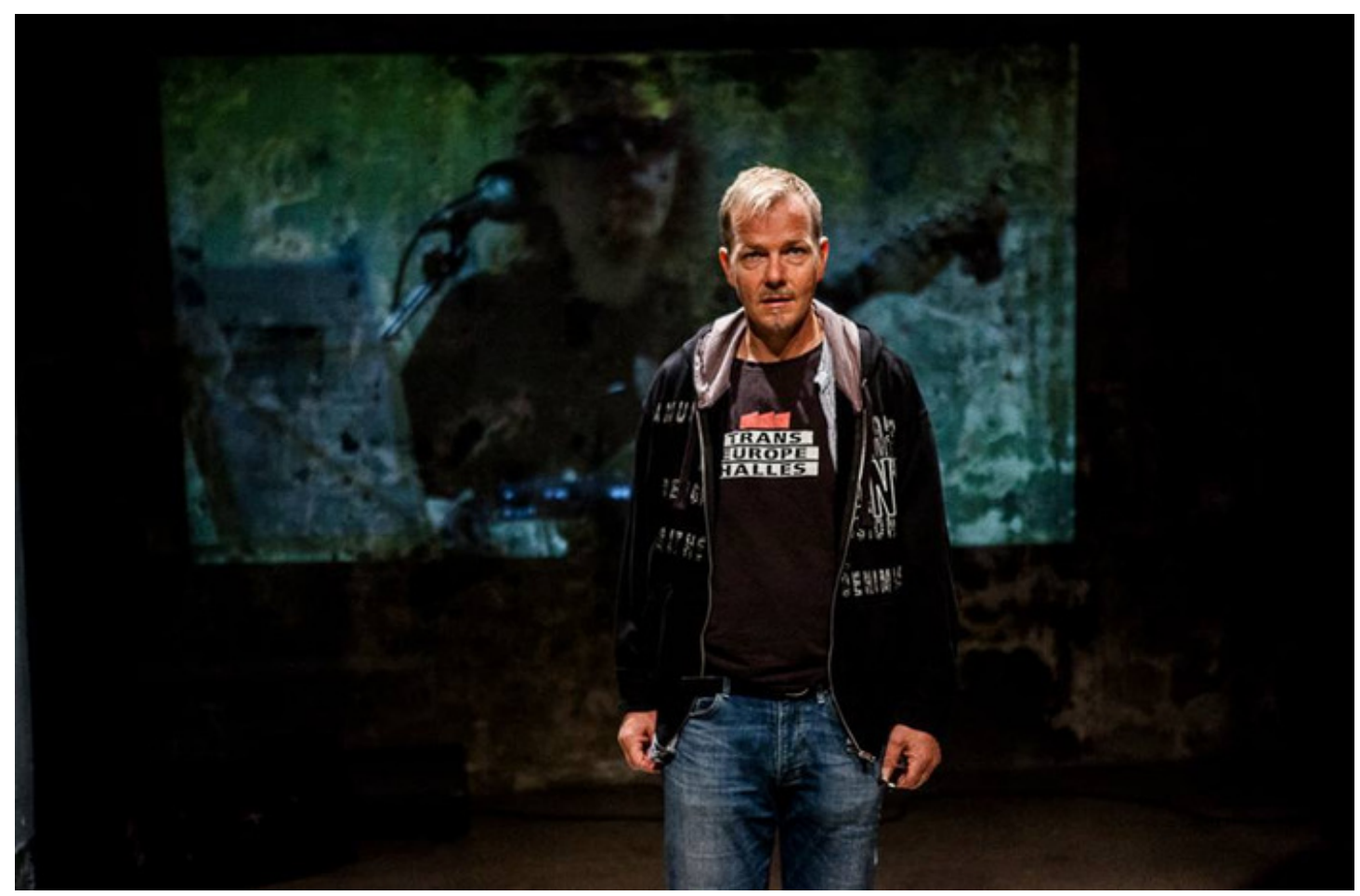

FIGURE 3. Q-teatteri: Ruusula Street 10 (Ruusulankatu 10) by Jonna Wikström 11.9.2014. In the photo Juha Sääski. Photographer Terjo Aaltonen.

because it deals with contemporary events, perhaps something similar could be detected in Ruusula Street 10. The actors did not mediate over a temporal distance, but over social stigmas and prejudices that prevented communication. ${ }^{62}$ The residents had not lost their ability to speak, but their voices were not heard because they were perceived as "scary people"63. By sharing the stories on behalf of the original speakers the actors aimed at bridging the gap between the different "life-worlds" of the homeless residents and the well-todo audiences.

However, a comparison between the actors' performance and the original speech acts recorded on video clips showed that the appearances of the stage characters had clearly been softened and embellished. ${ }^{64}$ Although the actors repeated the verbatim lines quite accurately, they replaced the coarse habitus of the original speakers by more decent bodies and speaking manners - or, in Taylor's terminology, they performed a more appropriate repertoire while keeping the archived text intact. ${ }^{65}$ Wikström confirmed that they

62. Rokem 2000, 7.

63. There was a rock piece in the performance called "I am a scary person".

64. https://vimeo.com/67797956

65. Taylor 2003. 
had deliberately whitewashed some of the characters, which was understandable considering the aims of the production. The audiences were persuaded to empathize with the residents by subtly fictionalizing them, which paradoxically gave them more credibility as realistically portrayed persons. By doing this, the performance was also staging the expectations, biases, desires and fears of its presumed audiences, thus revealing the ultimate otherness and strangeness of the shelter residents in the play.

\section{MY PALESTINE - THE THEATRE OF SUBJECTIVE MEMORIES}

My Palestine (Minun Palestiinani) was an autobiographical play by the prizewinning actor Noora Dadu, dealing with her Finnish-Palestinian background with the Middle-eastern conflict as a pretext for the play. ${ }^{66}$ Dadu preferred to call her performance "a theatre of personal memory" rather than a documentary theatre.67 She displayed her own experiences alternately with lectures on world politics, creating a subjective perspective on factual information. As a spectator, I was completely carried away by her humorous, yet touching performance, based on a combination of stand-up comedy, object theatre and dramatized scenes. The play was a sell-out: it premiered in the small venue of Teatteri Takomo in Helsinki; but soon moved to the larger Ryhmäteatteri.

In an early phase of the show, Dadu shared a memory, which became a key story for my reception of the play. She recalled being at theatre rehearsals with her friends when they heard the first news about the 9/11 attacks in 2001 and run to watch TV. Suddenly, Dadu felt silently excluded as if her friends would think that her half-Palestinian parentage made her guilty of Arab terrorism. However, at the end of the performance Dadu told, how she had later discussed the events with her friends and they all remembered the situation differently, even disagreeing amongst each other. When Dadu examined the case closer, she realised that they had not even been together at the moment when the news reached Finland.

Although this little story may seem just a common incident, proving the unreliability of human memory and the subjectivity of personal experiences, it drew my attention to my own process of believing in facts in a performative situation. At first, I empathized strongly with Dadu's disquiet about the unjust exclusion. The new information did not only make me correct my interpretation of the events, but more importantly, to look back at my own susceptibility of believing in facts. Dadu reflected on my observation: "It is good to notice 


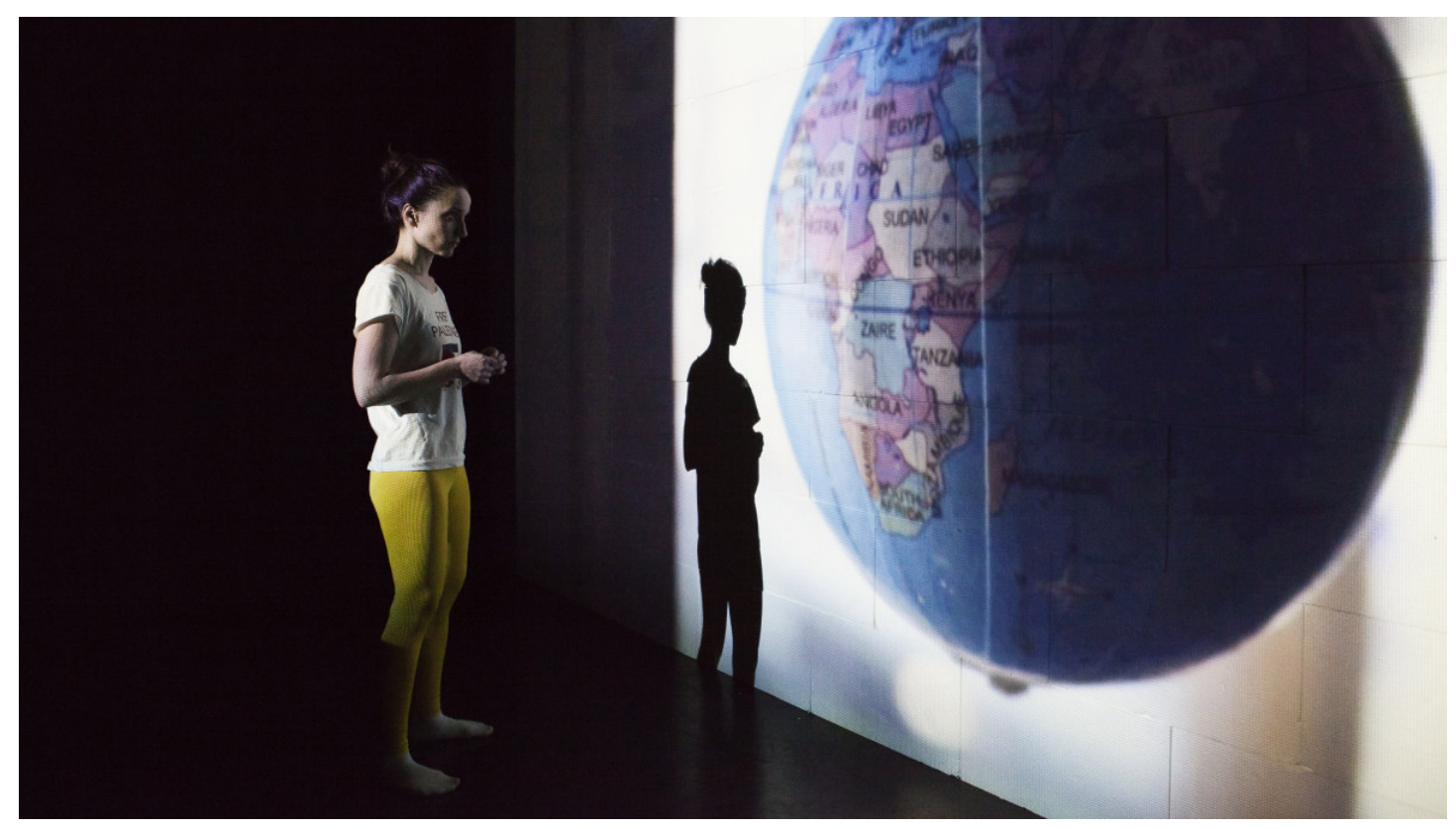

FIGURE 4. Teatteri Takomo: My Palestine (Minun Palestiinani) by Noora Dadu 28.3.2015. In the photo Noora Dadu. Photographer Mitro Härkönen.

that one has been wrong. In a hopeless situation, the hope awakens when we realize that what we have been seeing is not true: that we can see things in another way and live in another way."68

\section{TO CONCLUDE}

In my reception, Dadu's performance caused a movement between emotional identification and critical reflection, typical for documentary art. According to Reinelt, the "promise of documentary" is based on the combination of phenomenological engagement and realistic epistemology. 69 A documentary performance tries to simultaneously give verifiable information and heightened subjective experiences. This synthesis gives documentary theatre its strength because it can turn blunt factual knowledge into absorbing narratives that enable the spectator to identify with the emotions and attitudes of other individuals. Yet, it can create a vicious circle, in which we, simply put, believe in facts because we can experience them in person, and we value the experience because we already know that it is based on facts. Through this combination, we are easily lured to believe uncritically in facts when we can experience that they fulfil our desires and support our sense of mental cohesion. Reinelt suggests that in an uncertain world of simulations, a "public re-

68. Dadu interview 20.4.2015. Translation LG.

69. Reinelt 2009. 
hearsal of facts" may be a way of building a meaningful narrative around them and a way of holding on to the very notion of the facts: 70 "[the audiences] know there is no raw truth apart from interpretation, but still, they want to experience the assertion of the materiality of events." 71 The perception of tangible data, which seems to correspond to one's belief system feels reassuring, especially in times of social and economic uncertainty and political polarization.

The frightening thing is that the same mechanisms, which make a documentary performance so appealing, are also operative in populism and posttruth politics. Yet, theatre can also make the spectator aware of these mechanisms exactly because of its fraudulent theatricality. The theatre is, in Martin's words, a place where the real and simulated, fact and fiction collide and depend on each other. ${ }^{72}$ You can never be sure, whether an actor really is who $\mathrm{s} /$ he claims to be, or whether $\mathrm{s} / \mathrm{he}$ is fooling you, since s/he is acting. To me, the strongest potential of documentary theatre lies in the capability of activating a meta-level awareness about this uncertainty. When this happens, the spectator is compelled to ask again and again how knowledge about unknowable reality is produced through performing different statements.

Perhaps verbatim techniques have become so popular partly because they basically make it possible to simultaneously make claims about reality and expose the mechanisms by which knowledge about reality is produced and legitimated by speech acts. They can make visible the difference between a recorded document and its use in the production of knowledge. Reality itself can be presented as mediated and inaccessible, while the statements and speakers can be put under scrutiny in the here-and-now presence of the performance. Verbatim quotations thus become sites for negotiations over heterogeneous stories and interpretations about past events, even if the ultimate truth seems to be beyond reach. At the same time, they call for social responsibility: the spectator is not only faced with epistemic questions, but with ethical and political ones as well.

70. Reinelt 2010, 39.

71. Reinelt, 2010, 39.

72. Martin 2010, 2. 


\section{References}

Auslander, Philip. 1992. Presence and Resistance. Postmodern and Cultural Politics in Contemporary American Performance. Ann Arbor: The University of Michigan Press.

Austin, J.L.1962. How to Do Things with Words. London: Oxford University Press.

Fischer-Lichte, Erika. 2008. The Transformative Power of Performance. Translation Saskya Iris Jain. London and New York: Routledge. (Ästhetik des Performativen, 2004.)

Forsyth, Alison \& Chris Megson. (eds.) 2009. Get Real. Documentary Theatre Past and Present. Houndmills, Basingstoke, Hampshire: Palgrave Macmillan.

Forsyth, Alison. 2009. "Performing Trauma: Race Riots and Beyond in the Work of Anna Deavere Smith" in Forsyth \& Megson (eds.) 2009, 140-150.

Guénoun, Denis. 2007. Näyttämön filosofia. Translation Kaisa Sivenius, Esa Kirkkopelto and Riina Maukola. Helsinki: LIKE.

Hammond, Will \& Steward, Dan. (eds.) 2008. Verbatim, verbatim, contemporary documentary theatre. London: Oberon Books.

Junttila, Janne. 2012. Dokumenttiteatterin uusi aalto. Helsinki: Like.

Kuparinen, Susanna. 2013. Monologisuudesta moniäänisyyteen. Journalistinen dokumenttiteatteri yhden totuuden maassa. Helsinki: Teatterikorkeakoulu, master thesis in theatre direction.https://helda.helsinki.fi/handle/10138/39566 accessed 24 March 2016.

Lehmann, Hans-Thies. 2009. Draaman jälkeinen teatteri. Translation Riitta Virkkunen. Helsinki: Like. (Postdramatisches Theater, 1999.)

Lyotard Jean-Francois, 1985. Tieto Postmodernissa yhteiskunnassa. Translation Leevi Lehto. Tampere: Vastapaino. (La condition postmoderne, 1979.)

Martin, Carol. (ed.) 2010. Dramaturgy of the Real on the World Stage. Houndmills, Basingstoke, Hampshire: Palgrave Macmillan.

Martin, Carol (2010) "Dramaturgy of the Real" in Martin (ed.) 2010, 1-14.

Nikitin, Boris \& Schlewitt, Carena \& Brenk, Tobias. (eds.) 2014. Dokument, Fälschung, Wirklichkeit. Materialband zum zeitgenössischen Dokumentarischen Theater. Berlin: Verlag Theatre der Zeit.

Nikitin, Boris. 2014. "Der unzuverlässige Zeuge" in Nikitin \& Schlewitt \& Brenk (eds.) 2014. 12-19. 
Numminen, Katariina. 2011. "Tekstin ja esityksen suhde nykyteatterissa" in Ruuskanen (ed.) Nykyteatterikirja. 2000-luvun alun uusi skene. Helsinki: LIKE. 22-39.

Paget Derek. 1987. "Verbatim Theatre': Oral History and Documentary Techniques" in New Theatre Quarterly 3, 317-336.

doi:10.1017/S0266464X00002463.

Reinelt Janelle. 2009. "The Promise of Documentary" in Forsyth \& Megson (eds.) Get Real. Documentary Theatre Past and Present. Houndmills, Basingstoke, Hampshire: Palgrave Macmillan. 6-23.

Reinelt, Janelle. 2010. "Towards a Poetics of Theatre and Public Events: In the Case of Stephen Lawrence" in Martin (ed.) Dramaturgy of the Real on the World Stage. Houndmills, Basingstoke, Hamshire and New York: Palgrave Macmillan, 27-44.

Renov, Michael. (ed.) 1993. Theorizing Documentary. New York and London: Routledge.

Renov, Michael. 1993. "Introduction: The Truth about Non-Fiction" in Renov, Michael. (ed.) 1993, 7-11.

Rokem, Freddie, 2000. Performing History. Theatrical Representations of the Past in Contemporary Theatre. lowa City: University of lowa Press.

Rosen, Philip. 1993 "Document and Documentary: On the Persistence of Historical Concepts" in Renov, Michael. (ed.) 1993. Theorizing

Documentary. New York and London: Routledge, 58-89.

Ruuskanen, Annukka (ed.) 2011. Nykyteatterikirja. 2000-luvun alun uusi skene. Helsinki: LIKE.

Sennett, Richard 1978. The Fall of Public Man. New York: Vintage Books.

Taylor, Diana. 2003. The Archive and the Repertoire. Performing Cultural Memory in the Americas. US: Duke University Press.

Tinfo Finnish Theatre Statistics

http://www.tinfo.fi/documents/teatteritilastot2014_verkko.pdf

accessed 21 September 2014

\section{PERFORMANCES AND VIDEOS}

Dadu, Noora 2015. Minun Palestiinani (My Palestine. Teatteri Takomo, premiere 28 March 2015. Performance seen 9 April 2015.

Haapala Laura - Linnapuomi Satu 2014. Työtä päin (Towards Work). Kouvolan teatteri, premiere 8 November 2014. Performance seen 13 November 2014, and a video recording at disposal.

Kuparinen, Susanna and team 2015. Eduskunta III (Parliament III). Ryhmäteatteri, Helsinginkatu stage, premiere 26 September 2015. Performance seen 24 September 2015.

"Eduskunta III, tervetulosanat" ("Parliament III, Welcome Words") TVprogram on YLE Teema, 6 August 2016, 20.00-20.15. 
Kuparinen, Susanna and team 2015. Eduskunta III (Parliament III). Yle Teema, 6 August 2016, 20.15-22.15.

Smith, Anna Deavere. Fires in the Mirror, https://www.youtube.com/watch?v=hnkrUJny0CE accessed 22 November 2016

Smith, Anna Deavere. Let Me Down Easy:

https://www.youtube.com/watch?v=uQ1OyKy9FwM, accessed 4 October 2016.

Wikström, Jonna 2014. Ruusulankatu 10 (Ruusula Street 10) Q-teatteri, stage Puolikuu, premiere 11 September 2014. Performance seen 17 September 2014 in Q-teatteri, and a video recording at disposal.

Wikström, Jonna 2014. Ruusulankatu 10 (Ruusula Street 10). Trailer https://vimeo.com/67797956, accessed 4 October 2016.

\section{PERFORMANCE REVIEWS:}

Hallikainen, Niko. "Teatterin tarve tänään” Teatteri ja tanssi 7/2015. http://www.teatteritanssi.fi/7717-teatterin-tarve-tanaan/ accessed 1 December 2016.

Kangas, Ilona. "Kehyskertomus" Turun Sanomat 28.9.2015.

http://www.ts.fi/kulttuuri/nayttamotaide/818071/Kehyskertomus, accessed 1 December 2016.

Mahlamäki, Hanna. "Näytelmä väittää: Juha Sipilä on kova ja osaamaton johtaja, josta media rakensi messiaan." Helsingin Sanomat 28.9.2015. http://www.hs.fi/arviot/teatteri/a1443320690675\# accessed 1 December 2016.

Porokuru, Pontus. "Eduskunta III - Teatteri tekee toimittajien työt" Kansan Uutiset 11.10.2015. http://www.kansanuutiset.fi/artikkeli/3443945-eduskuntaiii-teatteri-tekee-toimittajien-tyot, accessed 1 December 2016.

Suni, Annakaisa. "Kansanedustaja katsoi Eduskunta III:n: 'Kritiikki on aiheellista"' Vihreä Lanka 1.10.2015.

http://www.vihrealanka.fi/arki/kansanedustaja-katsoi-eduskunta-iiin-kritiikkion-aiheellista, accessed 1 December 2016.

Talvitie, Liisa. "Saarnaavaa teatteria" Apu, 28.9.2015. http://blogit.apu.fi/lampio/saarnaavaa-teatteria/ accessed 1 December 2016.

Vuorenrinne, Antti. "Eduskuntatarinan päätös: Kulukurirosvoiksi paljatuvat VM:n virkamiehet" Demokraatti 8.10.2015 http://demokraatti.fi/mustahuppuiset-valtiovarainministerion-virkamiehetloytyvat-tarinan-roistoiksi/ accessed 1 December 2016. 


\title{
INTERVIEWS
}

Haapala, Laura, recorded interview with the author, 27 February 2015.

Recording in the possession of the author.

Dadu, Noora, recorded interview with the author, 20 April 2015. Recording in the possession of the author.

Linnapuomi, Satu, recorded interview with the author, 23 January 2015.

Recording in the possession of the author.

Sivonen, Arto (activist in the Töölö-movement) 9 March 2015 phone

interview with the author.

Wikström, Jonna. Broadcasted interview in "Puheen Iltapäivä:

Dokumenttiteatteriesitys Ruusulankatu 10 murtaa ennakkoluuloja" ("The afternoon of talk: the documentary performance Ruusula Street 10 breaks prejudices") broadcasted 17 September 2014. Listened in YLE Areena 12 October 2014.

Wikström, Jonna, recorded interview with the author, 23 October 2014.

Recording in the possession of the author.

\begin{abstract}
AUTHOR
Laura Gröndahl holds the title of docent (adjunct professor) of theatre studies at Helsinki University. She was a member in the research project on journalistic documentary theatre at Tampere University in 2014-15. Before that she has acted as university lecturer in theatre and media studies at the universities of Tampere and Lapland, and as a professor in scenography at the Aalto University School of Arts and Design. Her first occupation was a stage designer, and she has worked in the theatre practice for twenty years. She received her doctoral degree at the University of Industrial Arts, Helsinki in 2004, after which she has published several scholarly articles in domestic and international journals, writing about documentary theatre, scenography and practices of theatre making.
\end{abstract}

